\title{
Antimicrobial Activity of Azadirachta indica (Neem) Leaf Extract on Some Bacteria
}

\author{
Ugwu Celestina Chibuzo*
}

Enugu State University of Science and Technology (ESUT) Enugu, Enugu State, Nigeria

*Corresponding author

Keywords

Azadirachta indica,

Staphylococcus aureus, Escherichia coli, Phytochemical constituents, Inhibition

Article Info

Accepted:

07 June 2019

Available Online:

10 July 2019

\section{A B S T R A C T}

The antimicrobial activity of Azadirachta indica leaf extract (Neem leaf) was carried out on Staphylococcus aureus, Pseudomonas aeruginosa (ATCC 27853) and Escherichia coli using the agar well diffusion method. Ethanolic, aqueous and methanolic extracts of the plant were used at varying concentrations of $200 \mathrm{mg} / \mathrm{ml}, 100 \mathrm{mg} / \mathrm{ml}, 50 \mathrm{mg} / \mathrm{ml}, 25 \mathrm{mg} / \mathrm{ml}, 12.5 \mathrm{mg} / \mathrm{ml}$, $6.25 \mathrm{mg} / \mathrm{ml}, 3.125 \mathrm{mg} / \mathrm{ml}$ and $1.56 \mathrm{mg} / \mathrm{ml}$ respectively. The three extracts were found to show a very high antimicrobial activity though the ethanolic extract possessed more activity than the methanolic and aqueous extracts. The minimum inhibitory concentration (MIC) was found to range from $1.56 \mathrm{mg} / \mathrm{ml}$ to 6.125 for the three extracts respectively. When compared with standard antibiotics, the ethanolic and methanolic extracts showed maximum inhibition on these organisms. The phytochemical analyses revealed the presence of alkaloids, saponins, tannins, glycosides, steroids, terpenoids, and reducing sugars. Leaf extract of Azadirachta indica is therefore recommended for the treatment of human infections associated with these organisms.

\section{Introduction}

The use of plant extracts in the treatment of diseases has become an important interest over the years. This is as a result of the fact that microorganisms are developing resistance to many drugs and as such created situation where some of the common and less expensive antimicrobial agents are losing effectiveness (Montefore et al., 1989). In view of this, there is an urgent need to find the alternative to chemotherapeutic drugs in disease treatment particularly those of plants origin which are easily available and have considerably less side effects (khulbe and Sati, 2009).

In the past, humans used plant to treat common infectious diseases and even long before mankind discovered the existence of microbes; the idea that certain plant had healing potential was well accepted (Rios and Recio, 2005). Specifically, the medicinal value of these plants lies in some chemical 
substances that produce a definite physiological action on the human or animal body (Edeoga et al., 2005). The most important of these bioactive constituents which are mainly secondary metabolites are alkaloids, flavonoids, tannins and phenolic compounds (Anyanwu and Nwosu, 2014). These phytochemicals are toxic to microbial cells. Medicinal plants generally contain a number of compounds which may be potential natural antibacterial for the treatment of common bacterial infections (Ratnasooriya et al., 2005). The aim of this study was to assess the antimicrobial activities of Azadirachta indica leaf extract (Neem leaf) on some pathogenic bacteria and compare them with those of standard antibiotics.

\section{Materials and Methods}

\section{Processing of plant samples}

Azadirachta indica leaves were collected from Umueze Primary School Compound, Agbani in Enugu State, Nigeria. The leaves were authenticated by a Botanist in the Department of Applied Biology and Biotechnology, ESUT. The leaves were washed in tap water, rinsed in sterile distilled water and dried for 10 days under room temperature. The dried leaves were then blended to powder with a clean kitchen blender (Sonik, Japan) and stored in air tight glass containers until required for preparation.

\section{Preparation of extracts}

50 grams of leaves of Azadirachta indica were weighed into conical flask and $200 \mathrm{ml}$ of extractant (water, ethanol and methanol) were added and left to extract at room temperature (Ugwu et al., 2017). This was done using all the three extractants. The extract solutions were filtered aseptically into another $100 \mathrm{ml}$ reagent bottle using a watt-man No 1 filter paper. The filtrates were placed into an evaporator at room temperature to drive-off the extractants and stored at $4^{0} \mathrm{C}$.

\section{Microorganisms preparation}

The test organisms used were all human pathogenic organisms of clinical origin and were obtained from urinary tract of infected patients attending ESUT Teaching Hospital, Packlane, Enugu, Enugu State. They are one species of Gram positive bacteria (Staphylococcus aureus) and two species of Gram-negative bacteria (Escherichia coli, Pseudomonas aeruginosa ATCC 27853). They were stored on a nutrient agar slant in the Department of Applied Microbiology and Brewing, Faculty of Natural Sciences, ESUT, where they were kept as stock cultures at $4^{\circ} \mathrm{C}$. Biochemical characterization was carried out on each of the test organisms for confirmation.

\section{Antimicrobial assay}

The antimicrobial assay of water, ethanol and methanol extracts of Neem leaves were performed by agar well diffusion method. To test antibacterial activity of Neem leaf extract, $0.8 \mathrm{~g}$ of each extract was dissolved in DMSO and then varying concentrations of the extracts $(200 \mathrm{mg} / \mathrm{ml}, 100 \mathrm{mg} / \mathrm{ml}, 50 \mathrm{mg} / \mathrm{ml}, 25 \mathrm{mg} / \mathrm{ml}$, $12.5 \mathrm{mg} / \mathrm{ml}$, and $6.25 \mathrm{mg} / \mathrm{ml}$ ) were obtained according to Maragathavalli et al., (2012).

A standard inoculum of $1.5 \times 10^{8}$ cells which matched $0.5 \mathrm{McF}$ arland standard was spread on the surface of sterile Muller Hinton agar plates in duplicates. A sterile $6 \mathrm{~mm}$ cork borer was used to make a hole on the Muller Hinton agar plates in which $0.1 \mathrm{ml}$ of each of the plant extracts were added. The plates were incubated at $37^{\circ} \mathrm{C}$ for $24 \mathrm{~h}$. The antimicrobial activity was detected by measuring zones of inhibition in millimetres. To test antibacterial activity of the synthetic antibiotics, standardized discs were also used and zones of inhibition were determined. 


\section{Determination of the minimum inhibitory concentration (MIC)}

This was determined using broth dilution method as described by Maragathavalli et al., (2012). The minimum inhibitory concentration was defined as the lowest concentration of the compound to inhibit the growth of microorganisms (Kumar et al., 2007).

Varying concentrations of the extracts $(200 \mathrm{mg} / \mathrm{ml}, 100 \mathrm{mg} / \mathrm{ml}, 50 \mathrm{mg} / \mathrm{ml}, 25 \mathrm{mg} / \mathrm{ml}$, $12.5 \mathrm{mg} / \mathrm{ml}, \quad 6.25 \mathrm{mg} / \mathrm{ml}, \quad 3.125 \mathrm{mg} / \mathrm{ml}$ and $1.562 \mathrm{mg} / \mathrm{ml}$ ) were prepared. $0.1 \mathrm{ml}$ of standardized test organisms was inoculated into the tubes containing the different concentrations of the extracts and controls were equally setup by using solvents and test organisms without extract. These were incubated for $24 \mathrm{~h}$ at $37^{\circ} \mathrm{C}$. The tube with least concentration of extract without growth after incubation was taken and recorded as the minimum inhibitory concentration.

\section{Phytochemical analysis}

The water and ethanol extracts of neem leaf were analyzed to test for the presence of the alkaloids, saponins, tannins, Terpenoids, flavonoids, glycosides, volatile oils and reducing sugars as described Odebiyi et al., (1978).

The tests are as follows:

\section{Test for alkaloids}

Five grams of the evaporated extract was boiled with $5 \mathrm{ml}$ of dilute $\mathrm{HCl}$ in a water bath for 5minutes. The mixture was cooled and filtered. And the filtrate was subjected to alkaloids test using Dragendoff's reagent.

The filtrate was treated with Dragendoff's reagent. The formation of a red precipitate indicates the presence of alkaloids.

\section{Test for flavonoids}

Three grams of the extract was treated with ethyl acetate solution, heated in water bath for 1 minute. The mixture was cooled and filtered. The filtrate was shaken with $1 \%$ Aluminium chloride solution and left for 10 minutes. The formation of yellow colouration indicates the presence of flavonoids.

\section{Test for saponins}

One gram of the extract was boiled with $5 \mathrm{ml}$ of distilled water for 5 minutes. The content was filtered while hot and the filtrate was treated with few drops of olive oil and vigorously shaken. The formation of emulsion indicates the presence of saponins.

\section{Test for tannins}

Two grams of the evaporated extract was boiled with $45 \%$ ethanol for 5 minutes. The mixture was cooled and filtered. Then, the filtrates were then treated with few drops of lead acetate solution. The formation of gelatinous precipitate indicates the presence of tannins.

\section{Test for glycosides}

One gram of the evaporated extract was boiled with $15 \mathrm{ml}$ of distilled water for 5 minutes in a water bath. The mixture was cooled and filtered. $0.2 \mathrm{ml}$ of Fehling's solution A and B was added to $5 \mathrm{ml}$ of the filtrate and further boiled for 2 minutes in a water bath. The formation of a brick red colouration indicates the presence of glycosides.

\section{Test for reducing sugars}

The plant extract was treated with Fehling's solution (A and B) in a test tube. The colour change from deep blue to brick red indicates the presence of reducing sugar. 


\section{Test for steroids}

Two ml each of concentrated sulphuric acid $\left(\mathrm{H}_{2} \mathrm{SO}_{4}\right)$ and acetic anhydride were poured into $5 \mathrm{ml}$ each of the aquoes extract samples. The colour changed from violet which indicates the presence of steroids.

\section{Test for oils}

About $0.2 \mathrm{~g}$ of the plant extract was pressed between filter papers and observed for transparency. A control was also prepared by placing 2 drops of olive oil on another filter paper and also observes for translucency. If the filter paper becomes transparent, it shows the presence of oils in the paste.

\section{Test for terpenoids}

Four milligrams of extract was treated with $0.5 \mathrm{ml}$ of acetic anhydride and $0.5 \mathrm{ml}$ of chloroform. Then concentrated solution of sulphuric acid was added slowly and red violet colour was observed for terpenoid.

\section{Data analysis}

Data were keyed into SPSS (version 16) and the average of each determined values were then presented in suitable table for simple descriptive statistics.

The MICs of the different Azadirachta indica leave in the different extraction solutions were compared with the values of the standard antibiotic drugs.

\section{Results and Discussion}

\section{Antimicrobial activity of the extract}

The results of the antimicrobial activity of the extract on the test organisms are shown in tables 1,2 and 3 .

The plant extract showed different degrees of inhibitions on the test organisms.

The ethanol extract had more activity on the test organisms than the other extracting solvents.

\section{Minimum Inhibitory Concentration (MIC) of the extract}

The results of the MIC of the extracts on the test organisms are shown in Table 4. The MIC of the three extracts was $1.562 \mathrm{mg} / \mathrm{ml}$ for the organisms respectively.

Table.1 Inhibition zone diameter of ethanolic extract of neem leaf ( $\mathrm{mm}$ )

\begin{tabular}{|l|l|l|l|l|l|l|l|l|}
\hline Test organism & $\mathbf{2 0 0}$ & $\mathbf{1 0 0}$ & $\mathbf{5 0}$ & $\mathbf{2 5}$ & $\mathbf{1 2 . 5}$ & $\mathbf{6 . 2 5}$ & $\mathbf{3 . 1 2 5}$ & $\mathbf{1 . 5 6 2}$ \\
\hline S. aureus & 22 & 19 & 17 & 14 & 14 & 11 & 11 & 0 \\
\hline E. coli & 18 & 16 & 15 & 14 & 13 & 12 & 10 & 0 \\
\hline P.aeruginosa (ATCC 27853) & 15 & 13 & 12 & 11 & 10 & 9 & 0 & 0 \\
\hline
\end{tabular}

Table.2 Inhibition zone diameter of methanolic extract of neem leaf $(\mathrm{mm})$

\begin{tabular}{|l|l|l|l|l|l|l|l|l|}
\hline Test organism & 200 & 100 & $\mathbf{5 0}$ & $\mathbf{2 5}$ & $\mathbf{1 2 . 5}$ & $\mathbf{6 . 2 5}$ & $\mathbf{3 . 1 2 5}$ & $\mathbf{1 . 5 6 2}$ \\
\hline S.aureus & $\mathbf{2 0}$ & $\mathbf{1 7}$ & $\mathbf{1 6}$ & $\mathbf{1 3}$ & $\mathbf{1 2}$ & $\mathbf{1 1}$ & $\mathbf{8}$ & $\mathbf{0}$ \\
\hline E.coli & 17 & 16 & 13 & 12 & 12 & 10 & 8 & 0 \\
\hline P.aeruginosa(ATCC 27853) & 13 & 11 & 10 & 9 & 8 & 0 & 0 & 0 \\
\hline
\end{tabular}


Table.3 Inhibition zone diameter of aqueous extract of neem leaf ( $\mathrm{mm}$ )

\begin{tabular}{|l|l|l|l|l|l|l|l|l|}
\hline Test organism & 200 & 100 & $\mathbf{5 0}$ & $\mathbf{2 5}$ & $\mathbf{1 2 . 5}$ & $\mathbf{6 . 2 5}$ & $\mathbf{3 . 1 2 5}$ & $\mathbf{1 . 5 6 2}$ \\
\hline S.aureus & 18 & 16 & 15 & 13 & 12 & 11 & 11 & 0 \\
\hline E.coli & 16 & 15 & 14 & 13 & 13 & 11 & 10 & 0 \\
\hline P.aeruginosa(ATCC 27853) & 13 & 12 & 11 & 10 & 8 & 8 & 0 & 0 \\
\hline
\end{tabular}

Table.4 Minimum inhibitory concentration $(\mathrm{mg} / \mathrm{ml})$ of neem leaf extract on test organisms

\begin{tabular}{|l|l|l|l|}
\hline Test organism & Water & Ethanol Extract & Methanol Extract \\
\hline S. aureus & 1.562 & 1.562 & 1.562 \\
\hline E. coli & 1.562 & 1.562 & 1.562 \\
\hline P.auruginosa(ATCC 27853) & 3.125 & 3.125 & 6.125 \\
\hline
\end{tabular}

Table.5 Antibiogram-zone of inhibition (mm) of antibiotics disc on test organisms

\begin{tabular}{|c|c|c|c|c|c|c|c|c|c|c|}
\hline Test Organisms & Zone & of Inhit & ion $(n$ & & & & & & & \\
\hline Gram +ve Bacteria & APX & $\mathbf{Z}$ & $\mathbf{A M}$ & $\mathbf{R}$ & CPX & $\mathbf{S}$ & SXT & $\mathbf{E}$ & PEF & $\mathbf{C N}$ \\
\hline Stapylococcus aureus & 0.0 & 19 & 0.0 & $\mathbf{0 . 0}$ & 22 & 18 & $\mathbf{0 . 0}$ & 15 & 18 & $\mathbf{0 . 0}$ \\
\hline Gram -ve Bacteria & $\mathbf{C}$ & OFX & SP & SXT & PEF & $\mathbf{S}$ & CPX & $\mathbf{A M}$ & $\mathbf{A U}$ & \\
\hline Esherichia coli & 20 & 17 & 17 & 20 & 16 & 21 & 18 & 0.0 & 0.0 & \\
\hline Key-word & & Gram +ve & & & & & & & & \\
\hline $\mathrm{APX}=\mathrm{Ampiclox}$ & & $S=$ Streptc & ycin & & tipro & xacin & & & & \\
\hline $\mathrm{Z}=$ Zinnacef & & $\mathrm{SXT}=\mathrm{Sep}$ & & & $\mathrm{CN}=$ & Genta & nycin & & & \\
\hline $\mathrm{AM}=$ Ampicillin & & $\mathrm{E}=$ Erythr & $y \operatorname{cin}$ & PEF & Reflacin & & & & & \\
\hline $\mathrm{R}=$ Rocephin & & & & & & & & & & \\
\hline Gram-ve & & & & & & & & & & \\
\hline $\mathrm{C} \mathrm{H}=$ Chlorampenicol & & $S=$ Streptc & ycin & SX1 & Septrin & & & & & \\
\hline $\mathrm{AU}=$ Augmentin & & $\mathrm{OFX}=\mathrm{Ta}$ & & & CPX & Cin & oxacin & & & \\
\hline $\mathrm{SP}=$ & & $\mathrm{AM}=\mathrm{Am}$ & illin & & Reflacin & & & & & \\
\hline
\end{tabular}

Table.6 Phytochemical result of neem leaf extracts

\begin{tabular}{|l|c|c|}
\hline Phytonutrients & Water & Ethanol Extracts \\
\hline Flavonoids & - & - \\
\hline Alkaloids & ++ & ++ \\
\hline Oils & - & - \\
\hline Saponins & + & ++ \\
\hline Tannins & ++ & + \\
\hline Glycosides & +++ & +++ \\
\hline Steroids & ++ & - \\
\hline Terprenoids & - & ++ \\
\hline Reducing sugars & ++ & ++ \\
\hline & & \\
\hline
\end{tabular}


Some synthetic drugs cause varying degrees of side effects, hence there is need for the development of plant based compounds which could be useful in meeting the demand for newer drugs with minimal side effects (Srivastava et al., 2000). In the present study, it was found out that ethanol extract of the Neem plant had appreciable effect on the test organisms (Table 1).

This study is in agreement with the work of Hala and Alfadhil (2015) who reported that Neem leaf inhibited the growth of some bacterial pathogens. Several studies have indicated that the ethanol extract of plant parts were more inhibitory than the aqueous extract. This is as a result of ethanol being a better extractant (Ke-qiary et al., 2001). This study is also in agreement with several studies (Orhue et al., 2014; Dhayenithi et al., 2010; Autade et al., 2015).The methanol extract in this study had effect on the test organisms (Table 2). This is in agreement with the work done by Maragathavalli et al., (2012).

Aqueous extract of the Neem leaves had appreciable effect on the test organisms (Table 3). Raja and his colleagues compared the antimicrobial efficacy of aqueous extracts of leaf of $A$. indica against human pathogenic bacteria. They found out that leaf extract exhibited strong antimicrobial activity against these bacteria at all the concentrations tested. This study is also in agreement with the works of Autade et al., (2015); Yerima et al., (2012); Priyadharsini et al., (2014)who stated that the leaf of this plant has inhibitory effect on $P$. aeruginosa.

The MIC values (Table 4) was found to range from $1.56 \mathrm{mg} / \mathrm{ml}$ to $6.125 \mathrm{mg} / \mathrm{ml}$ for ethanol, methanol and aqueous: thus indicating that evaluation of MIC is sufficient for measuring bacterial activity (Natrajan et al., 2000). The result of MIC showed that ethanol extract was more effective against the test organisms than other extract. The study showed that the standard antibiotics used as positive control compared well with the plant extracts (Table 5).
It is believed that the antibacterial activity of this plant is due to the presence of the phytochemicals.

Subapriya and Nagini (2005) reported that the presence of high concentrations of azadirachtins, querectin and $\beta$-sitoeterol in $A$. indica leaves might be responsible for strong antibacterial and antifungal activity. This study showed that the A. indica contains the following phytochemicals: alkaloids, glycosides, tannins and saponins (Table 6). Hence, these are actually the defensive mechanism of the plant against pathogens (Hafza, 2000). This study showed that $A$. indica leaf extract can therefore be used as a therapeutic agent.

\section{References}

Anyanwu, C. and Nwosu, G. C. (2011). Assessment of the antimicrobial activity of aqueous and ethanolic extracts of Piper guineense leaves. Journal of Medical Plant Research, 8(10): 436-440.

Autade, R.H., Saini, S., Reddy, P.G., Deorukhkar, S.C. and Padmajakshi, G. (2015). Effect of Neem extract against opportunistic bacterial and fungal pathogens associated with AIDS. International Journal of Current Microbiology and Applied Sciences, 4(3): 988-999.

Dhayanithi, N.B., Kumer, T.T. and Kathiresan, K. (2010). Effect of neem extract against the bacterial isolates from marine fish. Journal of Environmental Biology, 31(4): 409-412.

Edeoga, H. O; Okwu, D. E, Mbaeble, B. O. (2005). Phytochemical constituents of some Nigerian medicinal plants. African Journal of Biotechnology, 4: 685-688.

Hafia, R.E. (2000). Peptides antibiotics. Lancet, 349: 418-422.

Hala, A.M. and Aifadhil, A.O. (2015). Antibacterial activity of Azadirachta indica (Neem) leaf extract against bacterial pathogens in Sudan. American Journal of Research communication, 3(5): 246-251. 
Ke-qiang, C.A.O., Anrina, H.C. and Van Bruggen (2001). Inhibitory efficiency of several plant extracts and plant products on Phytophthora infestens. Journal of Agricultural University of Hebei, 1-9.

Khuibe, K. and Sati, S.C. (2009). Antibacterial activity of Boenninghavsenia albiflora Reichb (Rutaceae). African Journal of Biotechnology, 8(22): 6346-6348.

Maragathavalli, S., Brindha, S., Kaviyarasi, N. S., Annadurai, B. and Gargwar, S. K. (2012). Antimicrobial activity of leaf extract of Neem (Azadirachta indica Linn.). International Journal of Science and Nature, vol. 3(1): 110-113.

Montefore, D., Rotimi, Y.O. and AdeyemiDoro, F.A (1989). The problem of antibacterial resistance to antibiotics among strains from hospital patients in Lagos and Ibadan. Nigeria. Journal of Antimicrobial and Chemotherapy, 23: 604.

Orhue, P.O., Momoh, A.R, M., Igumbor, E.O. and Esumeh, F.I. (2014). Antibacterial effect of Azadirachta indica (Neem or Dongo yaro) parts on some urinary tract bacterial isolates. Asian Journal of Plant Science and Research, 4(2): 64-67.

Priyadharsini, P., Bhardwaj, S. and Sheeba, E. (2014). Isolation, Identification of microbial isolates from urinary tract infection patients and evaluation of antimicrobial activity using plant extracts. International Journal of Current Microbiology and Applied Sciences, 3(4): 153-160.

Raja, Y., Krishna, C., Lokanatha, O., Mamatha, S. and Damodar, C. (2013). Antimicrobial activity of Azadirachta indica (Neem) leaf, bark and seed extracts. International Journal of Research and phytochemical and Pharmacology, 3(1): 1-4.

Ratnasooriya, W.D., Jayakody, J.R., Premakumara, G.A. and Edriweera, E.R. (2005). Antioxidant activity of water extract of Scoparia dutcis. Fitoterapia, 76(2): 220-222.

Rios, J. 1. and Recio, M. C. (2005). Medicinal plants and antimicrobial activity. Journal of Enthopharmacology, 100: 80-84

Srivastava, A., Shukla, R, and Kumar, Y.N. (2000). Recent development in plant derived antimicrobial constituents. A Review. Journal of Medical Aromatic Plant Science, 20: 717-722.

Subapriya, R. and Nagini, S. (2005). Medicinal properties of Neem leaves: a review. Current Medical Chemotherapy on Anticancer Agents, 5(2); 149-160.

Ugwu, C. C., Ezeonu, I. M., Mbah-Omeje. K. N., Agu, C. C. and Onuorah, S. C. (2017). Evaluation of the Antimicrobial Effects of Syzygium aromaticum (Clove) and Garcinia kola (Bitter kola) extracts singly and in Combination, on Some Bacteria. World Journal of Pharmacy and Pharmaceutical Sciences, 6(12): 1-13.

Yerima, M.B., Jodi, S. M., Oyinbo, K., Marshana, H. M., Farouq, A. A., Junaidu, A. U., Al-Mustapha, M. N. and Shinkafi, A.L. (2012). Effect of Neem extracts (Azadirachta indica) on bacteria isolated from adult mouth. Nigerian Journal of Basic and Applied Sciences, 20(1): 64-67.

\section{How to cite this article:}

Ugwu Celestina Chibuzo. 2019. Antimicrobial Activity of Azadirachta indica (Neem) Leaf Extract on Some Bacteria. Int.J.Curr.Microbiol.App.Sci. 8(07): 431-437. doi: https://doi.org/10.20546/ijcmas.2019.807.053 